\title{
Research on Jewish National Customs and Religious Origins
}

\author{
Xiumiao Wang \\ Zaozhuang University, Institute of Tourism and Resources Environment, Shandong, Zaozhuang, China, \\ 277160
}

Keywords: Jewish People; Judaism; Festivals; Customs

\begin{abstract}
The Jewish nation is a wonderful work in the world's national forest, and the strange folk customs make the Jewish nation dazzling. Exploring the customs origins of the Jewish people and discovering their customs and the religious beliefs of the nation - Judaism has a very deep connection. This article traces the origin of the Jewish people and their Judaism, and examines the relationship between the three festivals of the Sabbath, the Passover, and the Atonement Day.
\end{abstract}

\section{Introduction}

The Jewish nation is a wonderful work in the world's national forest, and the strange folk customs make the Jewish nation dazzling. Exploring the customs of the Jewish people, discovering their customs and the religious beliefs of the nation - Judaism has deep ties. Judaism is the faith of the Lord, who created the universe from all things, from the ancestor of the Jewish nation Abraham. According to the Bible, about 3800 years ago, a man named Abram was instructed by the Lord to lead the whole family from the Euphrates River of the Middle East and the Urs in the south of the Tigris River Basin, for the land of Canaan "flowing milk and honey" [1]. The Bible records Jehovah God to let Abram leave his land, his family and his father's house, and let God command his land, and if he obey, he will make his seed a great nation, and God will bless him and his descendants, that his name be respected throughout the land, so that other countries also because of his blessing [2]. Abram was renamed "Abraham", meaning "the father of many nations."

And the sons of Abraham, the son of Abraham, were wrestled with the angel of the LORD, and the angel of the LORD changed his name to Israel, which means "with the wives of God," and Jacob had twelve sons, and became twelve tribes, and Judah One of the tribes, because of the escape of the famine in the land of Canaan, Jacob led the children to Egypt, after the Egyptian slaves, 430 years later, the Lord appeared to Moses, told Moses to lead the Israelites from Egypt, the Lord promised to them The land of the Canaanites was given to them. On the way to the wilderness, the Lord had promulgated the law through Moses to Israel, the "Mosaic Five", also known as the "Torah", so the core of the Jewish faith was that the Lord was the only one of the Israelites The creation of the universe of all things God. "Jehovah" is meant to be "I am". It is the God who says that he is the eternal omniscient one and the Israelites are the "voters" of the Lord, and will obey his law and worship him alone. Then the Israelites under the leadership of Joshua entered the land of Canaan, the establishment of the history of a strong state of Israel, in the period of David and Solomon reached the peak of prosperity after the separation of the State of Israel into the south and north. In 722 BC, the northern country was destroyed by the Assyrian Empire, and the people were taken captive to Assyria, and the ten tribes of Israel were gone; the tribe of the kingdom of Judah was killed by the Babylonian Empire in 586 BC, The tribe of the tribe of Judah, and the tribe of the tribe of Benjamin, and the tribe of the Levites, which is not among the twelve tribes of the Israelites, are the ancestors of the Jewish people today. Since then most of the 2000 years the Jews have lost their country. "Judah" and "Jewish" in Hebrew is a word YEHUDA, the Chinese translation of the general said the nation, translated as Jewish; said the place name translated as "Ye Hu Da", said the name translated as "Judah" [3]. The Jewish people in this long flow of time still show a strong national character, to maintain their own national unique culture of customs, and their national 
beliefs have a very close relationship, so Judaism is to maintain national identity Link [4]. Thus, Jewish folklore showed a strong symbol of Judaism. This article discusses the customs of the Jewish people of Israel, such as festivals, living customs and life etiquette, and traces the relationship between them and Judaism.

The Jewish people have a lot of traditional festivals, such as the Sabbath, the Day of Atonement, the Passover, the Seventh Festival, the Feast of Tabernacles, the Pu'er Day, which reflects the unique way of life of the Jewish people, The These festivals are related to the beliefs of Judaism, limited to space, this article only inspected the relationship between the three festivals and Judaism.

\section{Sabbath}

The concept of the Jewish nation is from the sunset of the first day to the sunset of the second day. The Sabbath is from the beginning of the sunset every Friday, after the sunset on Saturday, which is the day when the Jewish people are resting. On this day all the shops are closed, the bus Also stop running. Orthodox Jews cannot switch electrical buttons during the Sabbath, if they need electric appliances and they must be opened before sunset on Friday and have been open until Saturday sunset, or with automatic switch electrical appliances. It even cannot touch the money, matches and machines, a foolish atmosphere. The Sabbath comes from the Jewish faith. According to the Bible, God sent Moses to bring the Israelites out of Egypt and promulgated the Law of the Ten Commandments on Mount Sinai. The fourth commandment was about the Sabbath, and the Sabbath should be holy, But the seventh day is not allowed to work again, to rest in the presence of the Lord God, to listen to God's commandments [5], mind ideas can get a purification, the spirit of sublimation, labor six days to restore the body, through this The worship of the Sabbath reveals the special relationship between the Jewish people and God, and the evidence of the covenant between the Lord and the Jewish people, a sign that the Jewish people became God voters.

The God of Israel - the Lord God is majestic, and his law must be strictly observed, and if he violates his commandments, he will be punished, and the Bible repeats that it violates the Sabbath and works on the Sabbath day. , It is necessary to be executed [5] [p83]. For the LORD is a God who keeps his mercy, and his voters will bless them if they keep his law, that they may be blessed and blessed; if his voters neglect their And the commandment shall be cursed, and shall be cursed in the field in the city. Therefore, the Sabbath is of great significance to the Jews, and sometimes even a sign of whether or not the Jews are identified. Moses Maimonides, a great philosopher of the Jews who were regarded as saints, said that even if a person was in violation of all the law in Torah, he was considered a guilty Jews, but if he had desecrated the Sabbath, And then as a Jew [6]. "The Sabbath was so important to the Jews, so the orthodox Jewish believers still obeyed this ancient tradition in the modern world today.

\section{The Passover}

From the twelfth day of the twentieth day of the twentieth day of the twentieth day of the twentieth day of the twentieth day of the Jewish calendar, The Passover is an ancient grand festival of the Jewish nation, and every Jew sees this festival as important, as the Chinese see the New Year. Even those who are less devout usually rarely go to the church of the Jews, will be in the Passover Festival from all directions to go home, spend the holidays with their families. The birth of the Passover is as follows: When the Israelites were slaves in Egypt, the Lord God commanded Moses to save the Israelites from Egypt and to the land of Canaan, where the gods were "milk and honey". But because of the Egyptian block, God on the rise of the same disaster hit the Egyptians and the last disaster is the most important thing is to kill the eldest son of Egypt. God commanded the children of Israel to stay at home, slaughtered a cup of cakes, baked and painted the sheep's blood on the door, as a sign, and the extermination of the LORD sent over the people of Israel and did not kill the Israelites the eldest son. The Egyptians died because of all the eldest son overnight, and urged the Israelites to leave Egypt, and the Israelites had no time to do the fermented bread because they had left in a hurry. Then God commanded them to keep the Passover for generations, to 
commemorate that period of time, and to thank God for the salvation of God [5] [64].

Passover has a set of procedural festival etiquette, before the festival to remove all the fermented things at home, on the 14th after sunset, the whole family are sitting in one place, parents put on the first cup of red wine, thanks to God. Then we take turns to drink, then wash their hands, dipped in salt to eat bitter herbs. The youngest man on the table will ask up the origin of the Passover and the meaning of all the rituals that the Lord of Israel will bring out the history of the Egyptians, the lambs, the unleavened bread and the bitter herbs Meaning to explain the family carefully, and for God's old salvation and gratitude, while God gave the food and all the grace and thanks to God, and then we sing the "Bible" Psalms 113 and 114. Drink the second cup of wine, the Lord of the Lord will be a large unleavened bread, broke into pieces, thanks, in turn with two pieces of cake bitter herbs, dipped in with nuts, raisins and apples made of thick sauce, To the people who eat, and finally eat the lamb's flesh. After the blessings of each other to drink the third cup of wine; singing "Bible Psalms" 115 to 118, finished singing the fourth cup of wine,

The Passover is the day to commemorate the salvation of the Lord God, and is another important sign of the voters of the Lord.

\section{Atonement Day}

Atonement Day in the Jewish calendar is on the 10th day of the month, equivalent to the end of September or early October. It is the last day of the 10-day period of repentance from the Jewish New Year. At the beginning of the day of the month of the day of the day of the day of the day of the day of the day of the day of the day of the day of the day, Concentrate on the sin of the LORD God, and do not do it, and be put to death, whether you live in the house as a permanent example of generations [7] [p115-116].

Traditional Jewish believers do not wear shoes or belts at the Day of Atonement, wear shoes or canvas shoes to the halls, and usually women to avoid dressing, the Day of Atonement is held at sunset, beginning with a prayer, continuous fast for 25 hours and prayer, shows how evil is to man, but God still listens to the prayer of repentance and forgives forgiveness.

Traditionally, the high priest, as Moses had commanded, offered a goat to God and sent the other goat, the sheep of the assassination, to the wilderness, symbolically to bring the fault of the people, For the sanctuary and the tabernacle of the congregation, and the sacrifice of the sin offering shall be offered to the living male goat, and to acknowledge the sins and transgressions of the children of Israel, and to put their hands on the sheep's head, on the head of the sheep, and then send the sheep to the wilderness to go [7] [p109].

About 20 minutes after sunset, that is, the whole day of atonement is for almost 25 hours, the Jews will read "Israel, you want to listen." The Lord our God is the only Lord. [8] [p172] "Then With the long horns, the believers cross each other: "next year Jerusalem see", this sentence has been celebrated for two thousand years of blessing, expressed the Jews eager to end the drifting of exotic life, back to the land of Canaan hope.

\section{Conclusion}

The customs of the Jewish nation, whether it is the Sabbath, the Passover, or the Day of Atonement, have a profound relationship with the Jewish national beliefs. The customs of the three festivals are deeply imprinted on the Jewish religion, examining the religious beliefs of Judaism, National holiday customs has a very important significance.

\section{References}

[1] Gao Hongcun: "Jewish Mythology: Jewish Civilization Overview", Taipei: Oriental Press, 2008, pp. 10-11.

[2] Bible, Genesis, Chapter 12, verses 1 through 2 
[3] Dazhou, Zhen Tang, Xu Xiangqun: "Chinese people look at Israel", Xinhua Publishing House, 1990, pages 157-158

[4] Yang Shuqin: "Jewish ritual customs", Taipei: Oriental Publishing House, 2008

[5] The Bible, Exodus, Chapter 20, verses 8-11

[6] "The Bible, Exodus" Chapter 31, verses 12 to 16:

[7] Zhang Xin. The hero of the boat cannot be on the "Catcher in the wheat field" on the heroic prototype [J]. Journal of PLA Foreign Languages Institute .2006.7: 29 (4), 96

[8] "The Bible, Exodus" Chapter 12, verses 43 to 47: 